\title{
Mortality Related to Accidents Involving Two-Wheeled Motorized Vehicles at Donka National Hospital
}

\author{
Thierno Mamadou Cherif Diallo ${ }^{*}$, Sory Diallo², Farel Aboki ${ }^{3}$, Namandjan Traore ${ }^{1}$ \\ ${ }^{1}$ Unit of Legal Medicine, Donka National Hospital, Conakry, Guinea \\ ${ }^{2}$ Institute of Child Nutrition and Health, Conakry, Guinea \\ ${ }^{3}$ Emergency Department, Donka National Hospital, Conakry, Guinea \\ Email: *drcherif2003@yahoo.fr
}

How to cite this paper: Diallo, T.M.C., Diallo, S., Aboki, F. and Traore, N. (2020) Mortality Related to Accidents Involving Two-Wheeled Motorized Vehicles at Donka National Hospital. Health, 12, 63-70. https://doi.org/10.4236/health.2020.121005

Received: December 17, 2019

Accepted: January 14, 2020

Published: January 17, 2020

Copyright $\odot 2020$ by author(s) and Scientific Research Publishing Inc. This work is licensed under the Creative Commons Attribution International License (CC BY 4.0).

http://creativecommons.org/licenses/by/4.0/

\section{Open Access}

\begin{abstract}
Two-wheeled motorized road accidents are becoming increasingly frequent and are responsible for high mortality among a young and active population in developing countries. The objective of this study was to determine the mortality rate related to motorcycle accidents and to identify socio-demographic factors and accidental mechanisms. Methodology: This was a retrospective descriptive and analytical study involving 16,655 patients, including 312 deaths due to motorcycle accidents. The study took place from January 1, 2013 to December 31, 2017. Not all patients who died as a result of accidents involving equipment other than two motorized wheels were included in our study. The data were entered and analyzed using the Epi.info version software. For the comparison of qualitative data, we used Pearson's khi2. Results: We recorded 312 cases of death or $1.87 \%$ out of a total of 16,655 victims. Of the deceased victims, only 112 wore a protective helmet and 200 did not. The male predominance was clear $(p<0.0001)$. Fatal accidents were more frequent among $4 \mathrm{pm}$ and midnight $(p<0.0001)$. Conclusion: This study shows that two-wheeled motor vehicle accident mortality is a public health problem. Gender, occupation and time of occurrence of the accidents were most common factors associated with mortality. The effective establishment of an emergency medical assistance service (SAMU) in Conakry could improve the pre-hospital care of these traumatised people.
\end{abstract}

\section{Keywords}

Accident, Mortality, Motorcycle, Donka

\section{Introduction}

Long considered as a public health problem in developed countries, road acci- 
dents are nowadays a real global scourge, due to the high number of victims due to the mechanization of all sectors of the economy, but also and especially because of the modernization of road traffic [1]. Motorcycling has been growing rapidly for several years. This success is due in large part to the practical and fun nature of this mode of transport, particularly in urban areas where traffic density heavily penalizes travel. Also, the motorcycle conveys strong images associated with escape and the pleasure of moving freely [2] [3]. According to WHO statistics, each year nearly 1.3 million people die on the world's roads and another 20 to 50 million are injured, some of whom are disabled for life. Of these deaths, $90 \%$ occur in emerging and developing countries, mainly among the most vulnerable road users, motorcyclists with $23 \%$ [4]. The associated risk factors for injury and death of a motorcyclist are young age, lack of protection (helmet), poor visibility of the motorcyclist and his motorcycle compared to other road users [5]. In the United States, in 2016, motorcyclists were involved in $27 \%$ of fatal road accidents [6]. In France, in 2016, according to the National Interministerial Observatory of Road Security (ONIRS), motorcyclists accounted for $17.6 \%$ of all road accident fatalities [7]. In Guinea, in 2016, the Guinean Observatory for Road Safety and Urban Mobility (GORSUM) reported 16,364 cases of road accidents between 2011 and 2014, causing the death of 2288 people and 5700 serious injuries, or $13.98 \%$ mortality. Of these deaths, $29 \%$ are attributable to two-wheeled motorized vehicles [8]. The increase in mortality due to the increasing frequency of motorcycle taxis in the city of Conakry and the rarity of previous studies in our context motivated this study, whose objectives were to: determine the mortality rate related to motorcycle accidents and identify socio-demographic factors and accidental mechanisms.

\section{Material and Methods}

This was a retrospective descriptive and analytical study involving 16,655 patients, including 312 deaths due to accidents involving two-wheeled motorized vehicles. The study took place from January 01, 2013 to December 31, 2017 in the forensic medicine unit in collaboration with the emergency department of the Donka National Hospital in Conakry. The forensic medicine unit is responsible for medical-legal consultation and the management of the remains. All the bodies benefited from the forensic doctor's expertise, some were received directly from the accident site, others via the emergency service (body depot). Not all patients who died as a result of accidents involving equipment other than two motorized wheels (personal vehicle, bus and truck) were included in our study. Our data were collected from medical records, death registers and individual survey sheets including questions on socio-demographic data (age, sex, socio-professional category) and accident characteristics (time, day of the week, month of occurrence and accident mechanism). The data were entered and analyzed using Epi.info software version. 6 For the comparison of qualitative data, we used Pearson's khi2. 
The data were entered and analyzed using Epi.info software version. 6 For the comparison of qualitative data, we used Pearson's khi2.

The insufficiency of information on certain files constitutes the main limitation of this study.

\section{Results}

We recorded 312 cases of death or $1.87 \%$ of a total of 16,655 victims of accidents involving two-wheeled motor vehicles. Of the 312 cases of death, only 112 wore a protective helmet and 200 did not. In the majority of cases, deaths occurred outside the hospital (either at the accident site or during transport to hospital) with $1.18 \%(n=197 / 16,655)$. In $0.47 \%$ of cases $(n=79 / 16,655)$, death occurred in a hospital ward, in $0.22 \%$ of cases $(n=36 / 16,655)$ death occurred on arrival in the emergency room.

All ages were concerned with extremes of 1 year and 76 years. The majority of the deceased victims $1.48 \%(247 / 16,655)$ were between 15 and 44 years of age. The category of workers was the most concerned with $0.65 \%(108 / 16,655)$. The male predominance was clear with a sex ratio M/F of 4, 26 .

Fatal accidents were more frequent among $4 \mathrm{pm}$ and midnight with $1.03 \%$ (n $=171 / 16,655)$, the difference observed was very significant $(p<0.001)$. We did not find a relationship between days of the week and the occurrence of deaths ( $p$ $=0.227)$. Our results also show that the month was not associated with the occurrence of deaths due to two-wheeled vehicles $(p=0.213)$, the difference was statistically insignificant.

The most frequent accidental mechanism most frequently and most associated with death was motor-vehicle $(p<0.0001)$ the statistical difference was highly significant.

Among the deceased victims (Figure 1), lesions were mainly found in the cephalic region (head and neck) with $1.63 \%(n=271 / 16,655)$.

\section{Discussion}

This study shows that of the 16,655 victims of accidents involving two-wheeled motorized vehicles recorded during the study period, 312 or $1.87 \%$ had died. This mortality has increased steadily over the 5 years of study with an average annual increase of $0.22 \%$ (Figure 2).

All ages were concerned with extremes of 1 year and 76 years. The majority of victims (67.6\%) were between 15 and 44 years of age (Table 1). For Bah M L et al. the mean age was 36.88 years with extremes of 3 and 85 years, patients aged 30 to 44 years were the most frequently encountered with a rate of $36.88 \%$, followed by youth aged 15 to 29 years or $34.88 \%$ [9]. This youthful trend could be explained by the risky behaviour of young motorcyclists (speeding, alcohol or drug use, lack of helmets or permits, inexperienced, non-compliance with traffic lights [10] [11] [12] [13]. In our study, we observed that the male sex (Table 1), was more exposed to risk with a mortality rate of $1.52 \%$ compared to $0.35 \%$ for 


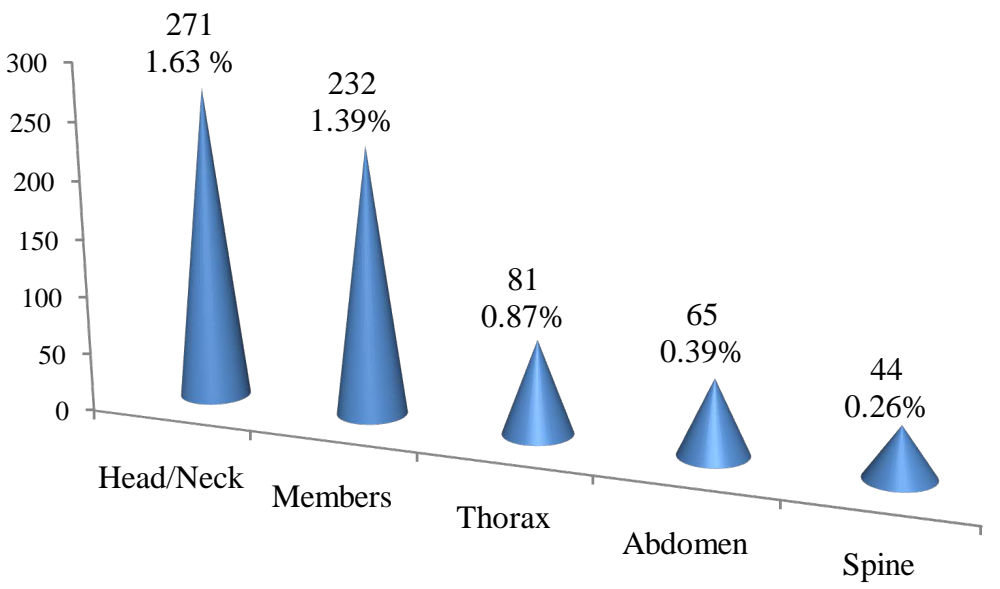

Figure 1. Distribution of deceased victims of death by injury location.

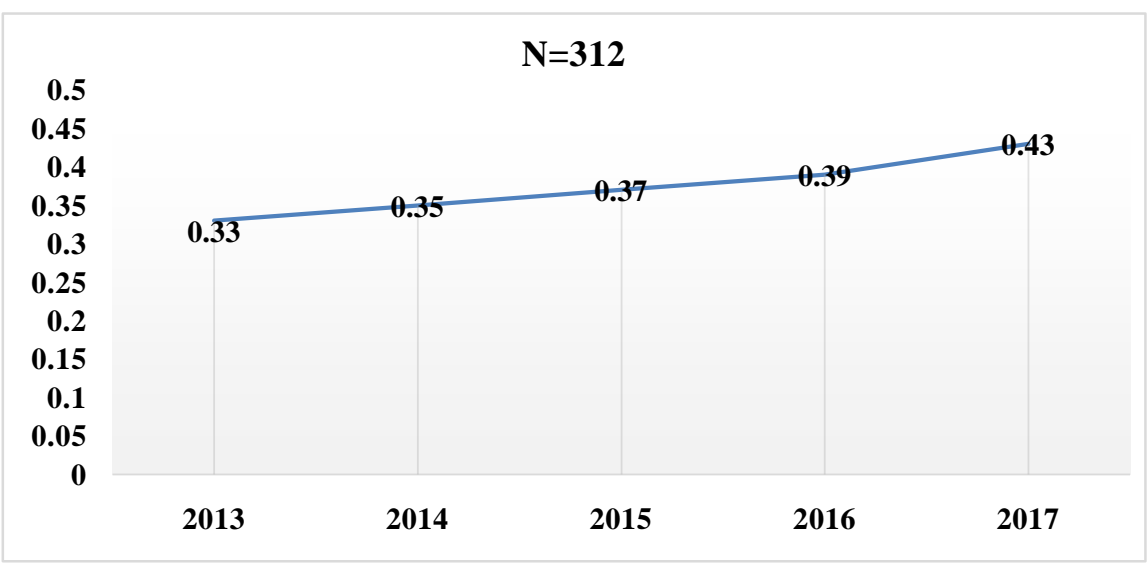

Figure 2. Evolution of mortality by year.

the female sex $(p<0.0001)$, the difference observed was statistically significant. This could be explained by the advent of motorcycle taxis, generally driven by men, as a new means of travel in our country, as in most countries of the subregion, as reported by many authors [9] [10] [13]. The breakdown by socio-professional (Table 1) category shows that the most concerned was that of workers with a mortality rate of $0.65 \%$, the difference observed was statistically significant ( $p=$ 0.0228 ). For many authors, the predominance among victims of accidents involving two-wheeled motorized vehicles among workers in the informal sector and pupils and students is explained by the explosion in the supply of low-cost motorcycles and the daytime activities requiring them to reach their workplace or study or home using these vehicles [10] [14].

In this study, we found that the time range from 4:00 pm to 00:00 am (Table 2). Strongly associated with the occurrence of deaths due to two-wheeled vehicles $(p<0.0001)$. This could be explained by the fact that this is the moment when all workers return home, but also and above all the moments when vigilance and reactivity decrease after the working day. We also observed that mortality from two-wheeled vehicles was seasonally variable. The months of June to 
Table 1. Distribution of deceased victims by socio-demographic characteristics.

\begin{tabular}{|c|c|c|c|c|c|}
\hline \multirow[t]{2}{*}{ Parametes } & \multicolumn{2}{|c|}{ Deceased } & \multicolumn{2}{|c|}{ Not deceased } & \multirow[t]{2}{*}{$p$-value } \\
\hline & $\mathrm{Nb}$ & $\%$ & $\mathrm{Nb}$ & $\%$ & \\
\hline \multicolumn{6}{|l|}{ Age group } \\
\hline$\leq 14$ ans & 32 & 0.19 & 1676 & 10.10 & \\
\hline $15-29$ ans & 129 & 0.77 & 6757 & 41.34 & \\
\hline $30-44$ ans & 86 & 0.52 & 4505 & 27.56 & \\
\hline $45-59$ ans & 36 & 0.22 & 1886 & 11.32 & $p=0.2202$ \\
\hline $60-74$ ans & 22 & 0.13 & 1152 & 6.91 & \\
\hline$\geq 74$ ans & 7 & 0.04 & 367 & 2.20 & \\
\hline \multicolumn{6}{|l|}{ Sex } \\
\hline Male & 253 & 1.52 & 13,252 & 81 & \\
\hline Female & 59 & 0.35 & 3091 & 19 & $p<0.0001$ \\
\hline \multicolumn{6}{|l|}{ Profession } \\
\hline Workers & 108 & 0.65 & 5658 & 34.62 & \\
\hline Students and students & 87 & 0.52 & 4556 & 27.88 & \\
\hline Trader/Merchands & 32 & 0.19 & 677 & 10.26 & \\
\hline Officials & 24 & 0.14 & 1256 & 7.69 & $p=0.0228$ \\
\hline Military & 21 & 0.13 & 1099 & 6.73 & \\
\hline Housewives & 19 & 0.11 & 997 & 6.10 & \\
\hline Cultivators & 12 & 0.07 & 629 & 3.85 & \\
\hline Others & 9 & 0.05 & 480 & 2.88 & \\
\hline
\end{tabular}

Table 2. Distribution of deceased victims by circumstances.

\begin{tabular}{|c|c|c|c|c|c|}
\hline \multirow[t]{2}{*}{ Parameters } & \multicolumn{2}{|c|}{ Deceased } & \multicolumn{2}{|c|}{ Not deceased } & \multirow[t]{2}{*}{$p$-value } \\
\hline & $\mathrm{Nb}$ & $\%$ & $\mathrm{Nb}$ & $\%$ & \\
\hline \multicolumn{6}{|l|}{ Hours } \\
\hline $16 \mathrm{~h}-00 \mathrm{~h}$ & 171 & 1.03 & 8957 & 54.81 & $p<0.0001$ \\
\hline $8 h-16 h$ & 77 & 0.46 & 4033 & 24.68 & \\
\hline $00 h-8 h$ & 64 & 0.38 & 3353 & 20.51 & \\
\hline \multicolumn{6}{|l|}{ Days } \\
\hline Monday & 40 & 0.24 & 2095 & 12.82 & \\
\hline Tuesday & 37 & 0.22 & 1938 & 11.86 & \\
\hline Wednesday & 32 & 0.19 & 1677 & 10.26 & $p=0.2270$ \\
\hline Thursday & 39 & 0.23 & 2043 & 12.50 & \\
\hline Friday & 50 & 0.30 & 2619 & 16.03 & \\
\hline Saturday & 66 & 0.40 & 3457 & 21.15 & \\
\hline Sunday & 48 & 0.29 & 2514 & 15.38 & \\
\hline \multicolumn{6}{|l|}{ Months } \\
\hline June-September & 98 & 0.59 & 5133 & 31.41 & \\
\hline October-December & 83 & 0.50 & 4348 & 26.60 & $p=0.2133$ \\
\hline April-June & 73 & 0.44 & 3824 & 23.39 & \\
\hline January-March & 58 & 0.34 & 3038 & 18.60 & \\
\hline
\end{tabular}


Table 3. Distribution of deceased victims by accidental mechanism.

\begin{tabular}{cccccc}
\hline Circumstances & \multicolumn{2}{c}{ Deceased } & \multicolumn{2}{c}{ Not Deceased } & $p$-value \\
\hline & $\mathrm{Nb}$ & $\%$ & $\mathrm{Nb}$ & $\%$ & \\
\hline Motorcycle/Auto & 179 & 1.07 & 9376 & 56.30 & \\
Motorcycle/Motorcycle & 72 & 0.43 & 3771 & 22.64 & \\
Motorcycle/Pedestrian & 34 & 0.20 & 1781 & 10.70 & $p<0.0001$ \\
Motorcycle only & 16 & 0.09 & 838 & 5.03 & \\
Motorcycle/Bicycle & 11 & 0.06 & 577 & 3.46 & \\
\hline
\end{tabular}

September were the most affected by deaths $(0.52 \%)$, however, the difference observed was not statistically significant $(p=0.2133)$. This period corresponds to the summer school holidays with their procession of intense juvenile recreational activities on the one hand, and on the other hand the poor state of the cycle paths associated with heavy winter rainfall could explain it [10].

The accidental motor-vehicle mechanism (Table 3 ) was strongly associated with death $(p<0.0001)$, the statistical difference was highly significant. According to some data in the literature, the motor-vehicle mechanism is predominant [9] [15] [16]. This predominance of fatal cases in motorcycle accidents could be explained on the one hand by the collision force that is to the detriment of motorcyclists, and on the other hand by the fact that these 2 means of transport are the most commonly used in our context.

Regarding helmet use, we found that motorcyclists who did not wear helmets were 1.5 times more likely to die than those who did $(p<0.0001) ; \mathrm{OR}=1.47$ [1.16 - 1.85]. This low proportion of motorcycle users wearing helmets could be explained on the one hand by poor enforcement of road safety legislation in our country, and on the other hand with poor information about users on the importance of wearing helmets. They often think that they should wear a helmet to avoid police control and not for their own safety. In France, the ORSFC (Fr-CTE Regional Health Organization) in 2003 and ACEM (Association of European Motorcycle Manufacturers) in 2008 reported helmet use at around $100 \%$ and 90.4\% respectively [15] [17]. Concerning the location of the lesions (Figure 1), the cephalic region (head and neck) was the most affected with $1.63 \%$, followed by the limbs with $1.14 \%$. This type of tissue damage demonstrates, on the one hand, the failure of motorcyclists to wear helmets and, on the other hand, the high velocity at which these accidents occur [10]. Helmet use reduces mortality and serious injuries after an accident [18] [19] [20].

In the majority of cases (1.18\%), deaths occurred outside the hospital (either at the accident site or during transport to the hospital). Most of the studies on road traffic accidents that have been carried out in low- and middle-income countries in the world have been carried out in a number of countries.

\section{Conclusion}

Two-wheeled motorized road accidents are becoming increasingly frequent and 
are responsible for high mortality among a young working population in developing countries. The regression of this phenomenon requires the implementation of a prevention policy through awareness campaigns on compliance with road traffic regulations, the wearing of protective helmets on the one hand, and on the other hand, through the effective implementation of an emergency medical assistance service (SAMU) in Conakry for the pre-hospital care of traumatised people.

\section{Conflicts of Interest}

The authors declare no conflicts of interest regarding the publication of this paper.

\section{References}

[1] World Health Organization (2004) World Report on Road Traffic Injury Prevention. WHO, Geneva.

[2] Regional Road Safety Observatory of Franche-Comté (2003) Study of the Physical, Psychological and Social Consequences of Accidents in Franche-Comté. ORSR, September, 1-4.

[3] Van Elslande, P., Fouquet, K., Vincensini, M., Nussbaum, F. and Roynard, M. (2008) Accidentology, Use and Representation of Two Motorized Wheels: Towards a Better Consideration of Their Diversity. Vol. 5, 1-27.

[4] World Health Organization (WHO) (2015) Summaries of Road Safety Situation Reports from around the World. Geneva.

[5] Hurt, H.H., Quellet, J.V. and Thom, D.R. (1981) Motorcycle Accident Cause Factors and Identification of Countermeasures. Volume 1: Technical Report. US Department of Transportation, National Highway Traffic Safety Administration, Washington DC.

[6] National Highway Traffic Safety Administration (2018) Traffic Safety Facts. Department of Transportation, Washington DC.

[7] National Inter-Ministerial Road Safety Observatory (2016) Road Safety in France. ONISR Balance Sheet.

[8] Guinean Observatory of Road Safety and Urban Mobility (2016) 1st Progress Report on Road Safety in Guinea. No. 1, 1-76.

[9] Bah, M.L., Sidibe, M., lamah, L., Bah, A.A., Bah, T.O. and Soumah, M.T. (2017) Motorcycle Accidents: Epidemiological Aspects and Injury Assessment at the Orthopaedic and Traumatology Department of the Ignace Deen National Hospital of the University Hospital of Conakry. Rev Int Sc. Med, 19, 57-61.

[10] Almeimoune, A., Mangane, M.I., Diop, T.H.M., Beye, S.A., Démbele, A.S., Koita, S., Coulibaly, M. and Diango, M.D. (2017) Epidemiological Aspects, Clinical Aspects of Road Traffic Injury (RTA) Involving Motorcycles in Bamako. RAMUR, 22, 64-67.

[11] Oluwadiya, K.S., Kolawole, I.K., Adegbehingbe, O.O., Olasinde, A.A., Agodirin, A. and Uwaezuokec, S.C. (2009) Motorcycle Crash Characteristics in Nigeria: Implication for Control K.S. Accident Analysis \& Prevention, 41, 294-298. https://doi.org/10.1016/j.aap.2008.12.002

[12] Linen, M.R. and Kraus, J.F. (2009) A Review of Risk Factors and Patterns of Motorcycle Injuries. Accident Analysis \& Prevention, 41, 710-722. 
https://doi.org/10.1016/j.aap.2009.03.010

[13] McGreevy, J., Stevens, K.A., Monono, M.E., et al. (2014) Road Traffic Injuries in Yaoundé, Cameroon: A Hospital-Based Pilot Surveillance Study. Injury, 45, 1687-1692. https://doi.org/10.1016/j.injury.2014.05.001

[14] Da, S.C., et al. (2008) Limb Fractures in Trauma Emergencies in Ouagadougou (Burkina Faso). J. Sci., 8, 1-9.

[15] Kudebong, M., Wurapa, F., Nonvignon, J., Norman, I., Awoonor-williams, J.K., et al. (2011) Economic Burden of Motorcycle Accidents in Northern Ghana. Ghana Medical Journal, 45, 135-142.

[16] Johnson, O.E. and Adebayo, A.M. (2012) Prevalence and Pattern of Road Traffic Accidents among Commercial Motorcyclists in a City in Southern Nigeria. Educational Research, 3, 537-542.

[17] José, G., Francine, D., Johny, E., René, H. and Gabriel, R. (2004) Ministère luxembourgeois du transport, La sécurité des deux roues motorisés. http://www.mt.public.lu/ministere/services/directioncirculationsécuritroutière/com missioncirculationétat/avis2rouesmotorises.pdf

[18] Bledsoe, G.H., Schexnayder, S.M., Carey, M.J., et al. (2002) The Negative Impact of the Repeal of the Arkansas Motorcycle Helmet Law. The Journal of Trauma, 53, 1078-1086. https://doi.org/10.1097/00005373-200212000-00009

[19] Ferrando, J., Plasencia, A., Oros, M., Borrell, C. and Kraus, J.F. (2000) Impact of Helmet Law on Two-Wheel Motor Vehicle Crash Mortality in a Southern European Urban Area. Injury Prevention, 6, 184-188. https://doi.org/10.1136/ip.6.3.184

[20] Diakite, A.K., Anzlania, D. and Camara, N.D. (2005) Accidental Death on the Public Road in Chu-Donka. Mali Medical, 20, 17-19. 